J. Lake Sci. (湖泊科学), 2014, 26(4): 485-496

http: //www. jlakes.org. E-mail : jlakes@niglas.ac.cn

(C) 2014 by Journal of Lake Sciences

\title{
滇池生态系统退化成因、格局特征与分区分步恢复策略”
}

\author{
李根保 ${ }^{1}$, 李 林 $^{1}$, 潘 珢 $^{2}$, 谢志才 ${ }^{1}$, 李宗逊 ${ }^{3}$, 肖邦定 ${ }^{1}$, 刘贵华 ${ }^{4}$, 陈 静 $^{5}$, 宋立荣 ${ }^{* * *}$ \\ (1: 中国科学院水生生物研究所淡水生态与生物技术国家重点实验室,武汉 430072) \\ (2: 昆明市滇池生态研究所, 昆明 650228) \\ ( 3 : 昆明市环境科学研究院, 昆明 650032 ) \\ (4: 中国科学院武汉植物园, 武汉 430074) \\ (5:云南省环境科学研究院, 昆明 650034)
}

摘 要: 选取生态系统中重要的组成成份: 浮游植物、底栖动物、水生植物的历史演变和现在分布状况数据, 结合水质变 化情况, 揭示了滇池生态系统退化原因: 在外因上, 污染物持续输人以及围湖造田、直立堤岸和水量交换缓慢等外力干扰 加剧系统组分失衡是直接原因; 在内因上, 由于滇池所处的地理位置、气候等原因, 蓝藻生物量对营养盐增加的响应远高 于其他湖泊 (太湖、巢湖), 草型向藻型湖泊的转换进程更快; 与太湖和东湖的生态系统比较, 高原湖泊滇池生态系统相对 脆弱, 如物种的同域分化、窄生态位, 导致系统的稳定性差、自我修复能力弱. 通过对滇池生态格局特征、湖岸带结构的分 析, 将滇池划分为 5 个生态区:草海重污染区、藻类聚集区、沉水植被残存区、近岸带受损区和水生植被受损区,并提出 “五区三步,南北并进,重点突破,治理与修复相结合” 的滇池生态系统分区分步治理的新策略和“南部优先恢复; 北部控 藻治污;西部自然保护;东部外围突破”的总体方案.

关键词: 滇池;退化成因;格局特征;生态分区;恢复策略

\section{The degradation cause and pattern characteristics of Lake Dianchi ecosystem and new restoration strategy of ecoregion and step-by-step implementation}

LI Genbao ${ }^{1}$, LI Lin ${ }^{1}$, PAN Min ${ }^{2}$, XIE Zhicai ${ }^{1}$, LI Zongxun ${ }^{3}$, XIAO Bangding ${ }^{1}$, LIU Guihua ${ }^{4}$, CHEN Jing ${ }^{5}$ \& SONG Lirong ${ }^{1}$

(1: State Key Laboratory of Freshwater Ecology and Biotechnology, Institute of Hydrobiology, Chinese Academy of Sciences, Wuhan 430072 , P. R. China)

(2: The Ecology Institute of Lake Dianchi, Kunming 650228, P. R. China)

(3: Kunming Institute of Environmental Science, Kunming 650032, P. R. China)

(4: Wuhan Botanical Garden, Chinese Academy of Sciences, Wuhan 430074, P. R. China)

(5: Yunnan Institute of Environmental Science, Kunming 650034, P. R. China)

Abstract: Combined with water quality changes, this paper analysed historical evolution data of phytoplankton, benthic animals, aquatic plants, important composition of ecological systems in Lake Dianchi, and revealed the reasons of degraded ecosystem: the direct cause is disturbances associated with sustained pollutant input, reclaiming land from the lake, building erect breakwater and slow water exchange. Because of Lake Dianchi's geographical location, climate and other reasons, the response of cyanobacterial biomass to nutrient increase is far higher than that of the other lakes (Lake Taihu, Lake Chaohu), which accelerating the shift of macrophytic lake to algal lake; Compared with the ecological system of Lake Taihu and East Lake, Lake Dianchi plateau lake ecosystem is relatively fragile, such as species of sympatric speciation, narrow niche, resulting in poor stability, weak ability of ecosystem recovery. Based on the analysis of ecological pattern, lakeside structure, Lake Dianchi was divided into five ecoregions:

* 国家水体污染控制与治理科技重大专项项目 (2008ZX07102-005) 资助. 2013-07-11 收稿;2013-12-30 收修改 稿. 李根保(1970 ), 男,博士, 副研究员;E-mail:ligb@ihb. ac. cn.

** 通信作者;E-mail:lrsong@ihb. ac. cn. 
heavy pollution region in Lake Caohai, algae accumulation region, aquatic submerged plants protection region, damaged lakeside region and aquatic vegetation damaged region. And then, we proposed a new restoration strategy of ecoregion and step-by-step implementation for the Lake Dianchi, and designed general scheme of the "Southern priority restoration; northern blooming algae and pollution control; western natural protection; eastern periphery breakthrough”.

Keywords: Lake Dianchi; degradation cause; pattern characteristics; ecoregion; restoration strategy

滇池是中国第 6 大淡水湖泊, 为西南云贵高原第一大淡水湖泊, 被誉为 “高原明珠” ${ }^{[1]}$. 滇池是昆明城市 备用饮用水源地之一, 具有工农业用水、调蓄、防洪、旅游、航运、水产养殖、调节气候等多种功能 ${ }^{[2-3]}$. 滇池湖 体分南北两水区, 中间有一航道相通. 北部水区称草海; 南部水区是滇池的主体部分, 称外海. 草海、外海水 体现今已完全由船闸大堤分隔, 湖面面积分别为 10.8 、298.2 $\mathrm{km}^{2}$ (1887.4 m 高程时). 由于滇池无大江大河 良好水源的注人, 自净能力十分有限, 加之由于社会经济迅速发展导致营养盐为主的污染物持续超量流人, 滇池生态系统退化, 产生严重的环境问题 ${ }^{[4]}$. 滇池也成为国内 “三河三湖” 中治理难度最大的湖泊. 近十几年 来, 国家和地方对滇池治理投人甚巨, 取得一定的成绩, 滇池水环境恶化的趋势总体得到遏制 ${ }^{[5-7]}$. 然而, 在 生态修复的治理理念和实践中, 缺乏对滇池生态系统现状和退化成因的科学和系统的认识, 采用的生态修 复技术和途径相对单一, 难以形成可行的生态修复方案和成套技术, 这些问题成为影响滇池水环境治理成 效的主要因素之一. 2008 年, 国家“水体污染控制与治理科技重大专项” (简称 “水专项”) “十一五”滇池项 目启动, 设立了 “湖泊生态系统退化调查与修复途径关键技术及工程示范”课题, 该课题设立了子课题 “湖泊 生态系统退化全面调查与生态系统恢复方案设计”. 在回溯滇池水生态演变历史和全面调查的基础上, 研究 分析了滇池生态系统退化成因, 解析了滇池生态格局特征, 提出了滇池生态系统分区分步恢复的总体方案, 以期促进滇池水环境治理思路转变. 本文系统介绍了上述研究结果和结论, 以期为滇池水环境治理和改善 以及类似水体的治理提供借鉴.

\section{1 滇池生态系统退化过程及原因}

\section{1 水质演变}

随着社会经济的发展, 人湖污染负荷逐年增加, 滇池水质逐年退化. 从 1970s 的 III类恶化到现在的 V 类, 局部甚至劣 V 类. 总磷 (TP) 浓度经过缓慢的增长阶段 (1960-1990 年), 到陡然跃升阶段 (1990-2000 年), 其后下降趋势明显, 经过 3 个阶段的变化, 外海水体仍为劣 $\mathrm{V}$ 类水平, 大约每 10 年变化 1 个等级. 而总氮 (TN) 浓度增长大体可分为 2 个阶段:第一阶段是 1960-2007 年, TN 浓度稳步上扬; 第二阶段为 2008 年至 今,变化趋缓,稍有下降(图 1).
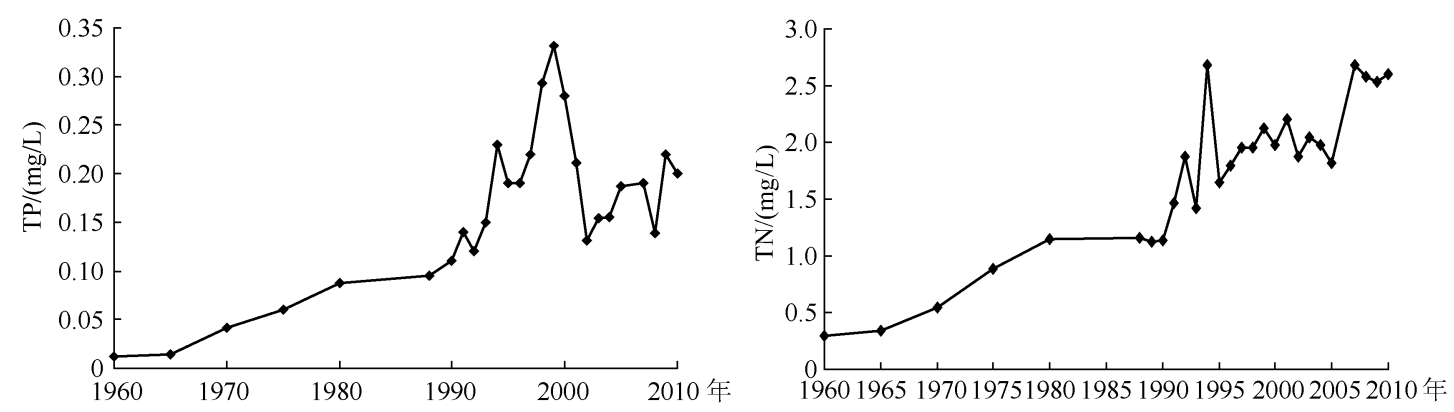

图 150 年来滇池外海总磷和总氮浓度的变化

Fig. 1 Changes of TN and TP concentrations in Lake Dianchi for 50 years

\section{2 水生态的演变}

伴随滇池水质污染的加重, 生态系统种群组成、结构和功能受到较大的影响, 表现为生态系统结构简 单, 一些功能退化甚至丧失. 本文就浮游植物、底栖动物和高等水生植物的演变来阐述滇池生态系统退化的 过程. 
1.2.1 浮游植物种类和生物量的演变 1 ) 浮游植物优势种的更替: 滇池浮游植物优势种更替较快 (表 1 ). $1950 \mathrm{~s}$ 滇池浮游植物优势种为绿藻门的鼓藻属、硅藻门的粗壮双菱藻 (Surirella robusta Ehr.) 和甲藻门 的角甲藻 (Ceratium hirundinella).

1980 s 优势种类变为绿藻门的栅藻属、盘星藻属, 硅藻门的直链藻属、波缘藻属、双菱藻属和蓝藻门的微 囊藻属, 优势种为硅藻门的颗粒直链藻 (Melosira granulata)、线形菱形藻 (Nitzschia linearis)、端毛双菱藻 (Surirella capronii Breb.)、线形双菱藻 (Surirella linearis W. Smith)、草鞋型波缘藻 (Cymatopleura solea), 蓝藻 门的铜绿微囊藻 (Microcystis aeruginosa) 、小颤藻 (Oscillatoria tenuis), 甲藻门的角甲藻, 绿藻门的葡萄藻 (Botryococcus braunii Kutz. )、单角盘星藻 (Pediastrum simplex ( Mey.) Lemm. )、单角盘星藻具孔变种 (Pediastrum simplex var. duodenarium (Bail.) Rabenh. ) 、二角盘星藻具孔变种 (Pediastrum duplex var. clathrarum)、转板藻 (Mougeotia sp.). 15 年前的优势种类鼓藻属仅剩 1 种, 且只在 1 个样点出现,粗壮双菱藻的优势地位被端毛 双菱藻所取代, 微囊藻属也成为优势种类.

$1990 \mathrm{~s}$ 滇池浮游植物优势种明显变为以蓝藻门植物占绝对优势, 束丝藻属、微囊藻属和颤藻属占很大的 优势, 尤其是 6 月份微囊藻占绝对优势. 绿藻门占优势的是细链丝藻 (Hormidium subtile), 栅藻属和盘星藻属 次之. 与 10 年前相比, 滇池浮游植物优势种类已由硅藻门、绿藻门植物演变为蓝藻门植物.

$2000 \mathrm{~s}$ 至今, 滇池浮游植物以蓝藻门微囊藻属占绝对优势, 水华束丝藻 (Aphanizomenon flos-aquae) 在早 春占优势, 绿藻门的四尾栅藻 (Scenedesmus quadricanda) 、硅藻门的颗粒直链藻最窄变种 (Melosira granulate var. angustissima) 也占一定的优势.

2) 浮游植物丰度的变化: 1992 年浮游植物的丰度 ( 5 个样点 3 个月份) 为 $0.014 \times 10^{6} \sim 2.350 \times$ $10^{6} \mathrm{cells} / \mathrm{L}$, 平均为 $0.656 \times 10^{6} \mathrm{cells} / \mathrm{L}$, 而 2001-2002 年浮游植物的丰度 (20 个样点 6 个月份) 为 $4.402 \times$ $10^{6} \sim 1.102 \times 10^{9} \mathrm{cells} / \mathrm{L}$, 平均为 $1.188 \times 10^{8} \mathrm{cells} / \mathrm{L}$, 上升 3 个数量级 ${ }^{[8-9]} .2009-2010$ 年, 全湖浮游植物的 丰度 $\left(24\right.$ 个样点 11 个月份) 平均值为 $1.42 \times 10^{8} \mathrm{cells} / \mathrm{L}$.

表 1 滇池浮游藻类种数的变化 ${ }^{*}$

Tab. 1 Change of the number of phytoplankton species in Lake Dianchi

\begin{tabular}{|c|c|c|c|c|c|c|c|c|c|c|}
\hline \multirow{2}{*}{ 门类 } & \multicolumn{2}{|c|}{$1956-1963$ 年 } & \multicolumn{2}{|c|}{$1982-1983$ 年 } & \multicolumn{2}{|c|}{$1988-1989$ 年 } & \multicolumn{2}{|c|}{$2001-2002$ 年 } & \multicolumn{2}{|c|}{$2009-2010$ 年 } \\
\hline & 属 & 种 & 属 & 种 & 属 & 种 & 属 & 种 & 属 & 种 \\
\hline 绿藻门 & 46 & 94 & 32 & 90 & 31 & 73 & 22 & 50 & 34 & 76 \\
\hline 硅藻门 & 22 & 36 & 15 & 48 & 13 & 22 & 16 & 33 & 13 & 28 \\
\hline 蓝藻门 & 15 & 26 & 19 & 45 & 12 & 17 & 10 & 20 & 16 & 33 \\
\hline 裸藻门 & 5 & 13 & 4 & 11 & 3 & 8 & 2 & 2 & 3 & 4 \\
\hline 轮藻门 & 4 & 7 & - & - & - & - & - & - & 1 & 1 \\
\hline 甲藻门 & 4 & 5 & 4 & 7 & 2 & 3 & 1 & 1 & 2 & 2 \\
\hline 黄藻门 & 2 & 3 & 1 & 1 & - & - & - & - & 1 & 1 \\
\hline 金藻门 & 2 & 2 & 1 & 2 & 1 & 1 & - & - & - & - \\
\hline 隐藻门 & - & - & 1 & 1 & 2 & 2 & 1 & 1 & 2 & 5 \\
\hline
\end{tabular}

$* 2002$ 年前的数据来自文献 $[8]$ 和文献 $[9]$.

1.2.2 底栖动物种类和生物量的演变 自 1940s 以来, 滇池共记录底栖动物 85 种, 隶属于 3 门 6 纲 28 科. $1940 \mathrm{~s}$ 记录 51 种, 1970s 记录 33 种, 1980s 记录 57 种, 1990s 记录 21 种, 2002 年记录 13 种 $^{[10]}$. 从 1940s 到 $1980 \mathrm{~s}$ 总体上呈现稳定的趋势, 但是从 $1980 \mathrm{~s}$ 至今,物种数显著降低.

本次调查 $(2009-2010$ 年)共记录到大型底栖动物 32 种,隶属 3 门 4 纲 9 科,主要由极度耐污的寡毛 类——霍甫水丝蚓 (Limnodrilus hoffmeisteri) 、正颤蚓( Tubifex tubifex) 等组成, 高原湖泊特有的软体动物几乎 消失殆尽, 仅存少量的螺蛳 (Margarya melanioides)、牟氏螺䗗 (M. mondi)、光肋螺䗗 (M. mansugi) 、滇池圆田 螺 (Cipangopaludina dianchiensis). 与 1980s 相比, 滇池底栖动物群落的物种损失率高达 $44 \%$, 其中软体动物 损失率高达 $75 \%$, 其次是水生昆虫 $(39 \%)$.

近 20 年来, 滇池底栖动物的密度和生物量发生较大的变化 (图 2). 1990s 初底栖动物相对较少, 寡毛类 
密度和生物量分别为 138 ind. $/ \mathrm{m}^{2}$ 和 $6.78 \mathrm{~g} / \mathrm{m}^{2}$ (分别占总量的 $19.8 \%$ 和 $48.0 \%$ ), 摇蚊科的密度和生物量分 别为 558 ind. $/ \mathrm{m}^{2}$ 和 $7.35 \mathrm{~g} / \mathrm{m}^{2}$ (分别占总量的 $80.2 \%$ 和 $52.0 \%$ ) $^{[11]}$. 而 2002 年底栖动物的丰度达到峰值, 其中葟毛类密度和生物量分别为 $4609 \mathrm{ind} . / \mathrm{m}^{2}$ 和 $18.02 \mathrm{~g} / \mathrm{m}^{2}$ (分别占总量的 $91.9 \%$ 和 $81.2 \%$ ), 摇蚊科密度 和生物量分别为 $408 \mathrm{ind} . / \mathrm{m}^{2}$ 和 $4.18 \mathrm{~g} / \mathrm{m}^{2}$ (分别占总量的 $8.1 \%$ 和 $\left.8.8 \%\right)^{[12]}$. 本研究调查结果显示, 滇池全 湖底栖动物密度和生物量分别为 $1776 \mathrm{ind} . / \mathrm{m}^{2}$ 和 $3.43 \mathrm{~g} / \mathrm{m}^{2}$, 其中㘯毛类密度和生物量分别为 $1706 \mathrm{ind} . / \mathrm{m}^{2}$ 和 $2.83 \mathrm{~g} / \mathrm{m}^{2}$ (分别占总量的 $96.1 \%$ 和 $82.6 \%$ ), 摇蚊科密度和生物量分别为 $68 \mathrm{ind} . / \mathrm{m}^{2}$ 和 $0.60 \mathrm{~g} / \mathrm{m}^{2}$ (分别 占总量的 $3.8 \%$ 和 $17.4 \%)^{[10]}$. 这些数据表明塞毛类和摇蚊科对湖泊富营养化进程带来的水环境变化表现 出两种不同的响应.
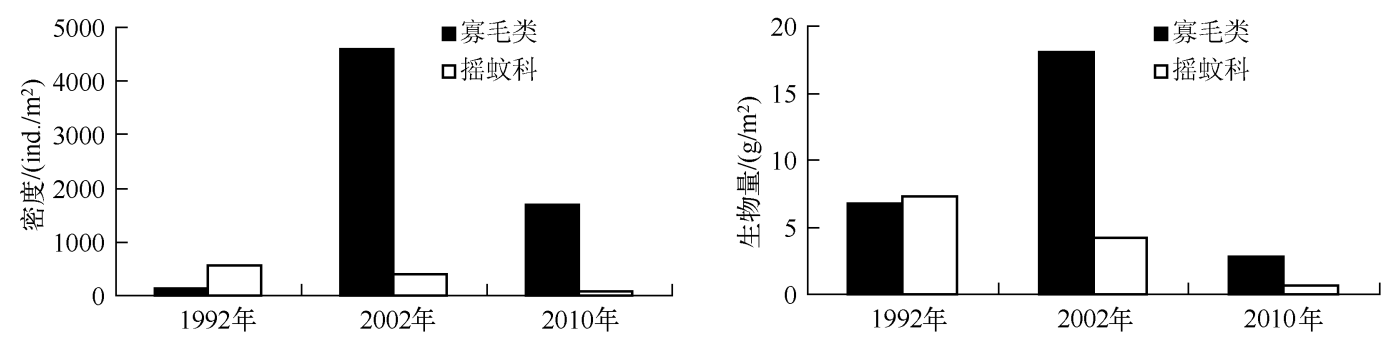

图 2 近 20 年滇池大型底栖动物主要类群密度和生物量的演变 ${ }^{[10]}$

Fig. 2 Density and biomass variations of main macrozoobenthos groups in Lake Dianchi across nearly twenty-year span

1.2 .3 水生植物种类和生物量的演变 由于污染和人类对湖泊生态系统的干扰加剧, 滇池的水生植被在 1960s 至 1980s 初期发生了急剧变化 (图 3), 主要表现在种类数和物种多样性减少, 一些不耐污的种类甚至 完全消失; 分布面积迅速减少, 生物量下降, 建群种趋于单一, 耐污染、抗风浪的高体型沉水植物雚齿眼子菜 (Potamogeton pectinatus) 成为优势种群.

$1950 \mathrm{~s}-1960 \mathrm{~s}$ 滇池水生植被覆盖度大约占湖面面积的 $90 \%$, 水生植物物种丰富, 水深 $4 \mathrm{~m}$ 以内的湖体 都有水草生长, 特别是草海部分, 是百草繁茂的沼泽化水域. 全湖以适宜清水环境生长的海菜花 (Ottelia acuminata) 和轮藻为全湖的优势种类, 滇池北岸及东岸芦苇呈条带状分布.

1970s 后滇池水生植被在短短的 10 年间发生了剧烈的变化: 随着 1970s 开展的史上最大规模的围海 造田的开展, 滇池水生植被面积大幅度减少, 水生植被所占面积由五六十年代的 $90 \%$ 突然降到不足 $20 \%$; 优势群落变化显著, 原来占绝对优势的高原湖泊特有物种海菜花 $1970 \mathrm{~s}-1980 \mathrm{~s}$ 已渺无踪迹, 马来眼 子菜、轮藻等沉水植被也很难再看到, 取而代之的是狐尾藻群落成为优势群落, 具有完整演替序列的东、 南岸带, 原本连片分布的芦苇群落也大面积消失; 同时还表现出植物种群密度下降、生物产量大大下降等 特点.

1980s 在昆明城市经济快速发展、人口不断增加的同时, 工业废水及城市污水收集处理措施的严重滞 后, 使得处于下游的滇池接纳了大量的工、农业及生活废水, 滇池水体富营养化日益严重, 水体透明度显著 下降, 水生植物的分布范围进一步减少, 沉水植物逐渐向湖滨浅水区迁移, 仅有占湖泊面积 $2.05 \%$ 的水域有 水生植被分布.

目前滇池水体的光补偿点不到平均水深的 $20 \%$, 大大增加了恢复沉水水生植被的难度. 自 $1990 \mathrm{~s}$ 以来, 滇池的水生植被尤其是沉水植被在经历了大幅度衰减后已经趋于相对稳定,变化不大.

\section{3 生态系统退化原因分析}

1) 造成滇池水生态系统严重受损的原因是多方面的. 生境破坏使得滇池生态系统的生境片段化,生境 变化是生态系统过程变化的基础.

(1) 生境破坏: 沿岸带是水陆生态交错带的一种类型, 是指相邻的陆地生态系统与水域生态系统之间的 过渡带, 历来是人类活动最集中的场所, 也是地球上最易受到破坏的湿地生态系统之一. 湖滨带的功能主要 表现为湖滨水陆交错带内生物或非生物因素的相互作用, 对交错带内能量流动和物质循环的调节, 以及在 
景观斑块的变化或稳定性中所起的作用. 1950s - 1970s 进行的围湖造田,使滇池很多重要的湖湾、沿岸 “沟 潭” 被夷为平地. 而这些湖湾、龙潭及之间的连接沟渠是水生植物分布的重要区域,也是鱼虾等重要栖息和 繁殖区域,尤其是一些土著物种重要的栖息地. 但随着这些“沟潭”系统被改造成农田、鱼塘之后,这些区域 水生植物群落遭受严重破坏,生物多样性急剧下降. 滇池水生生态系统的稳定性也大大降低. 1958、1963、 1964 和 1970 年,围湖造田面积分别为 7.47、1.20、0.756 和 $20 \mathrm{~km}^{2}$, 相当于 $1958-1970$ 年间滇池水体系统缩 减了 $29.4 \mathrm{~km}^{2}$. 在 1970 年有史以来最大范围的围湖造田 $\left(20 \mathrm{~km}^{2}\right)$ 完工后, 滇池水生植被遭受了致命性的打 击. 总之,围湖造田使滇池水体直接损失了近 $30 \mathrm{~km}^{2}$ 的水生植物分布的重点区域,使滇池生物多样性遭受严 重破坏,生态系统稳定性下降, 自净能力降低.
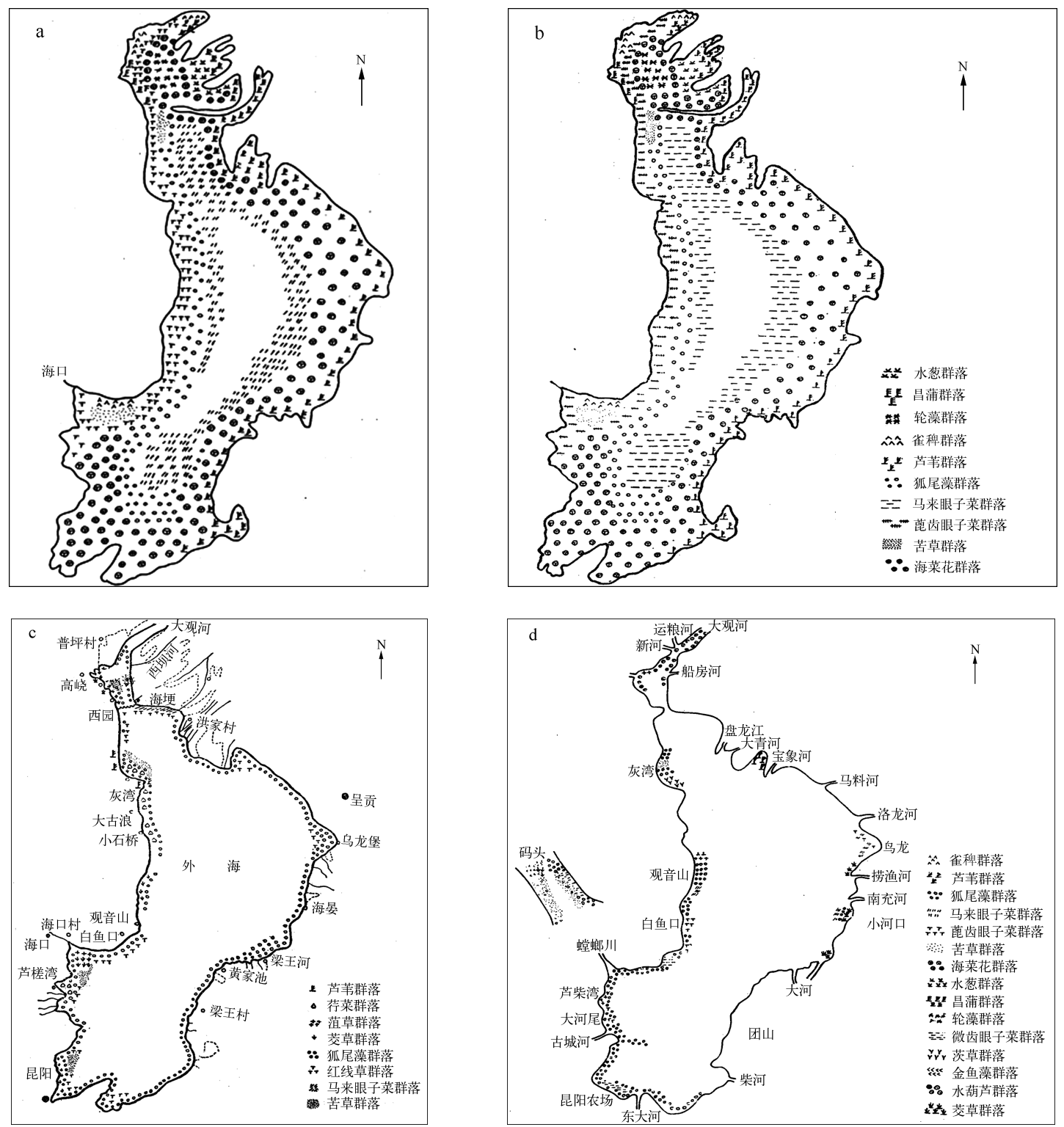

图 $31950 \mathrm{~s}(\mathrm{a}) 、 1960 \mathrm{~s}(\mathrm{~b}) 、 1970 \mathrm{~s}(\mathrm{c})$ 和 $1980 \mathrm{~s}(\mathrm{~d})$ 滇池水生植物群落分布演变 ${ }^{[8,13]}$

Fig. 3 Distribution of aquatic plants community in Lake Dianchi in 1950s(a),1960s( b) ,1970s(c) and 1980s (d) 随着 $1990 \mathrm{~s}$ 滇池防浪堤的建成,滇池和陆地水陆交错带被阻断,滇池成了相对孤立的名副其实的 
表 2 滇池各县区防浪堤概况

Tab. 2 Breakwater in each county around Lake Dianchi

\begin{tabular}{ccc}
\hline 县区 & 防浪堤总长度 $/ \mathrm{km}$ & 完好程度 $/ \%$ \\
\hline 西山区 & 24.45 & 86 \\
官渡区 & 31.83 & 近 100 \\
呈贡县 & 23.55 & 80 \\
晋宁县 & 37.03 & 88 \\
\hline
\end{tabular}

“悬湖”. 滇池防浪堤总长 $117 \mathrm{~km}$ (表 2), 防浪 堤隔离了滇池, 外围陆地上则是密集的鱼塘、 大棚、菜地等. 湖滨带是滇池的生态保护屏障, 是水陆物质循环和能量流动的区域, 是生物活 动最为频繁的区域, 也是生物多样性最丰富的 区域. 滇池外海沿岸带天然湿地系统被毁, 丧 失了沿岸带所特有的生境多样性, 滇池湖泊生 态系统的植物群落变得脆弱.

(2) 水质恶化: 从 1980s 开始, 随着滇池流域 人口增长及社会经济的发展, 滇池污染负荷逐步加剧. 到 $1980 \mathrm{~s}$ 末、1990s 初, 滇池进人了富营养化阶 段. 富营养化导致的结果是浮游植物的季节性增长, 对水生植物的生长产生了很大影响. 很多脆弱不 耐污的物种消失. 目前, 滇池存在的物种多为耐污物种, 且因富营养化的影响, 其分布范围、生物量都 有所降低. 同时由于水体进人富营养化状态, 蓝藻水华也季节性暴发, 浮游藻类在湖泊中占绝对优势, 占据着水体上层空间, 优先利用光照及可摄取态养分元素, 水体透明度严重下降使湖中水生植物分布 面积缩小, 生物量也降低, 很多耐受性差的物种如海菜花等甚至消失, 促使滇池由 “草型” 湖泊转向 “藻 型” 湖泊. 目前滇池水体的光补偿点不到平均水深的 $20 \%$, 大大增加了恢复沉水水生植被的难度.

因此, 生境的片段化是滇池生态系统退化的主要外因, 持续的营养输人以及人为强力改造滇池地理结 构使得滇池生态系统结构连续性和完整性被严重破坏, 物种多样性的下降使滇池生态系统的稳定性和抗干 扰能力严重下降, 湖泊自净能力和生态功能基本丧失.

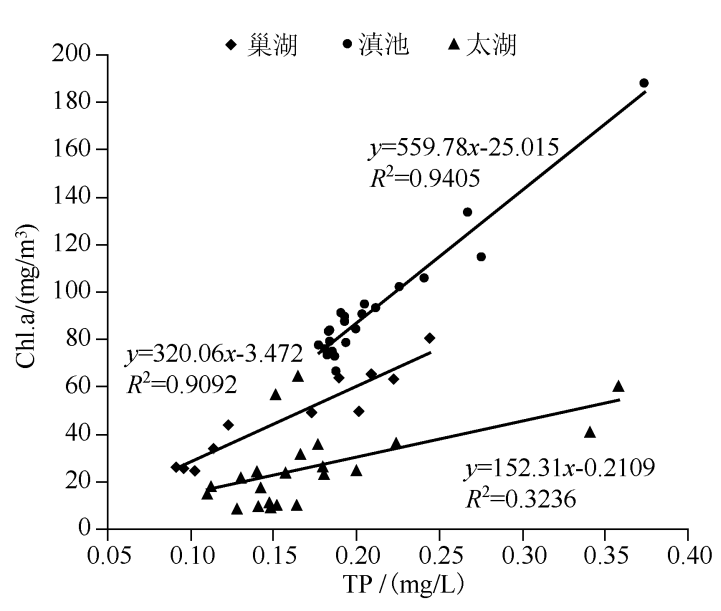

图 4 滇池、太湖和巢湖叶绿素 $\mathrm{a}$ 含量对磷的响应

Fig. 4 Response of chlorophyll-a contents to phosphorus in Lake Dianchi, Lake Taihu and Lake Chaohu

表 3 滇池、太湖和东湖生态系统特征比较

Tab. 3 Comparison of the ecological characteristics among Lake Dianchi, Lake Taihu and Lake Donghu

\begin{tabular}{lrrr}
\hline 生态系统特征 & 滇池 & 太湖 & 东湖 \\
\hline Finn 循环系数 & 5.55 & 8.43 & 28.41 \\
Finn 平均能量路径 & 2.37 & 2.47 & 4.35 \\
初级生产力/总生物量 & 151.17 & 31.17 & 29.26 \\
\hline
\end{tabular}

2) 蓝藻生长对营养盐的响应突出.

1990s 以后, 水华暴发问题突出. 每年的 410 月, 在水温和光照等适宜环境因子的驱动下, 滇池微囊藻水华盛达全湖 $300 \mathrm{~km}^{2}$. 通常受西南 主导风向及湖流影响, 水华集聚到滇池外海北部 离岸 $100 \sim 1000 \mathrm{~m}$ 的浮藻堆积区. 大量堆积的水 华蓝藻腐败后散发阵阵臭味, 不仅严重影响景 观, 而且对生态系统本身也产生负效应. 近几年 来, 滇池全湖性的蓝藻水华情况相对 1990s 强度 有所减轻, 全年叶绿素 a(Chl. a) 浓度在 $100 \mu \mathrm{g} / \mathrm{L}$ 左右波动, 蓝藻水华情况仍然比较严峻. 与太湖、 巢湖相比, 在相同 TP 浓度下 (2008 年 9 月至 2010 年 10 月 3 湖逐月采样数据), 滇池表现为 较高的 Chl. a 含量及较快的藻类增长速率 (图 $4)$. 本文分析认为: 滇池的水温特征有利于藻类 快速复苏和藻类生物量的维持, 沉积物及水柱中 有机物转化为无机氮、磷的周转速率快, 为滇池 藻类生长提供了充足的营养.

3) 高原湖泊生态系统相对脆弱, 如物种的 同域分化、窄生态位, 导致系统的稳定性差、自我 修复能力弱.

比较滇池、太湖和东湖的生态系统特征 (表 3 ), 可以发现滇池生态系统的 Finn 循环系数和 Finn 平均能量路径比太湖和东湖要低. Finn 循环 系数越低, 反映系统受扰动后恢复时间越长, 自 
我修复能力越低. 而湖泊的初级生产力与总生物量的比值却比其他湖泊高, 说明滇池生态系统结构很不合 理,能量传递效率降低,大量初级生产力未进人食物网并得到有效利用.

\section{2 滇池生态格局特征及生态分区}

\section{1 水体理化特征}

在滇池, 营养物、水生生物分布的生态系统格局异质性特征明显. 滇池外海营养盐含量呈现分区分布的 特征, 由北向南逐步减轻(图 5). 滇池草海不同区域的污染也呈现显著的梯度差异. 分析滇池底泥各监测指 标在不同季节和区域的差异及空间分布,将滇池分为 8 个区,分别为内草海区、外草海区、外海西北区、外海 东北区、外海东岸区、外海东南岸区、外海中部区和外海西南区(图 5).
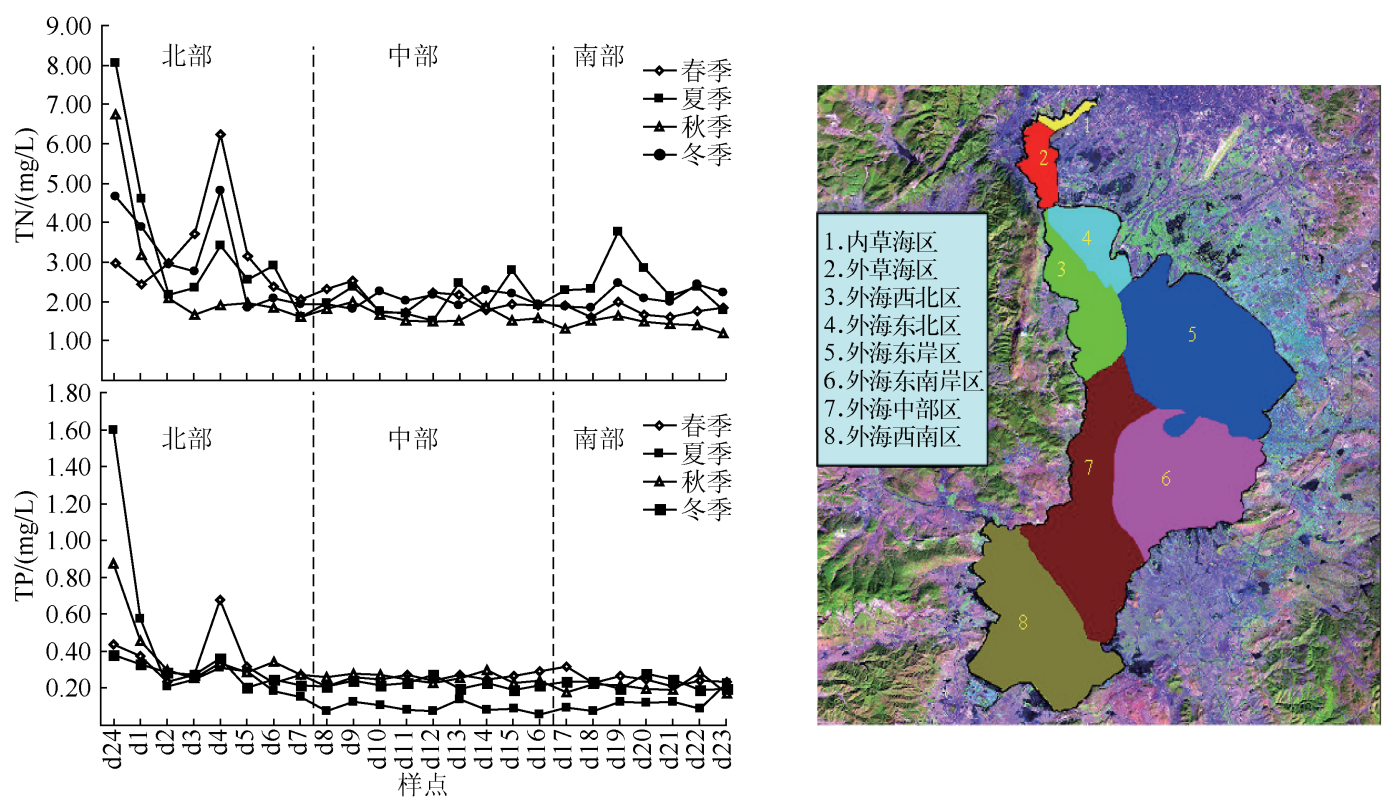

图 5 滇池主要营养盐季节分布与底泥分区特征

Fig. 5 Seasonal distribution of nutrient and sediment division feature in Lake Dianchi

\section{2 水生态特征}

2.2 .1 浮游植物的分布现状 滇池各生态组分 空间分布的特点也呈现空间异质性. 浮游植物 的分布呈现北高南低的态势, 可分为北部、中 部和南部 3 部分. 在 2009 年 1-12 月期间, 浮 游植物的密度平均值为 $1.77 \times 10^{8} \mathrm{cells} / \mathrm{L}$, 变 幅在 $0.83 \times 10^{8} \sim 3.95 \times 10^{8}$ cells $/ \mathrm{L}$ 之间 (图 6).

2.2.2 种子库的分布现状 种子库的分布对于 水生植物恢复具有重要的作用. 对滇池底泥中 种子库的调查发现,滇池南部和北部皆有种子 库的分布 (图 7 ). 在数量和种类上, 滇池南部 和西岸种子库较为丰富.

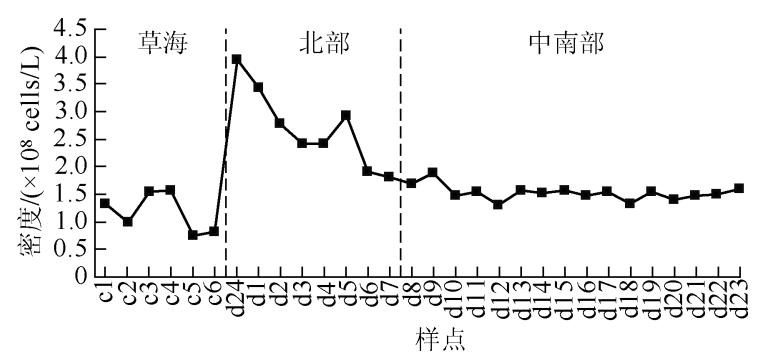

图 6 滇池 2009 年 1-12 月浮游藻类密度的空间分布

Fig. 6 Spatial distribution of phytoplankton density in Lake Dianchi from January to December of 2009

2.2.3 滇池水生植被的分布现状 滇池的挺水植物群落主要分布在近岸季节性淹水的区域,历史上占据优 势的挺水植物芦苇形成的群落萎缩到只有盘龙江人湖口、海门湖滨及其它零散区域小范围分布. 
漂浮植物群落是滇池分布面积很大的水生植物群落, 主要分布在相对静水区域, 但也会随着水流与风 浪而移动.
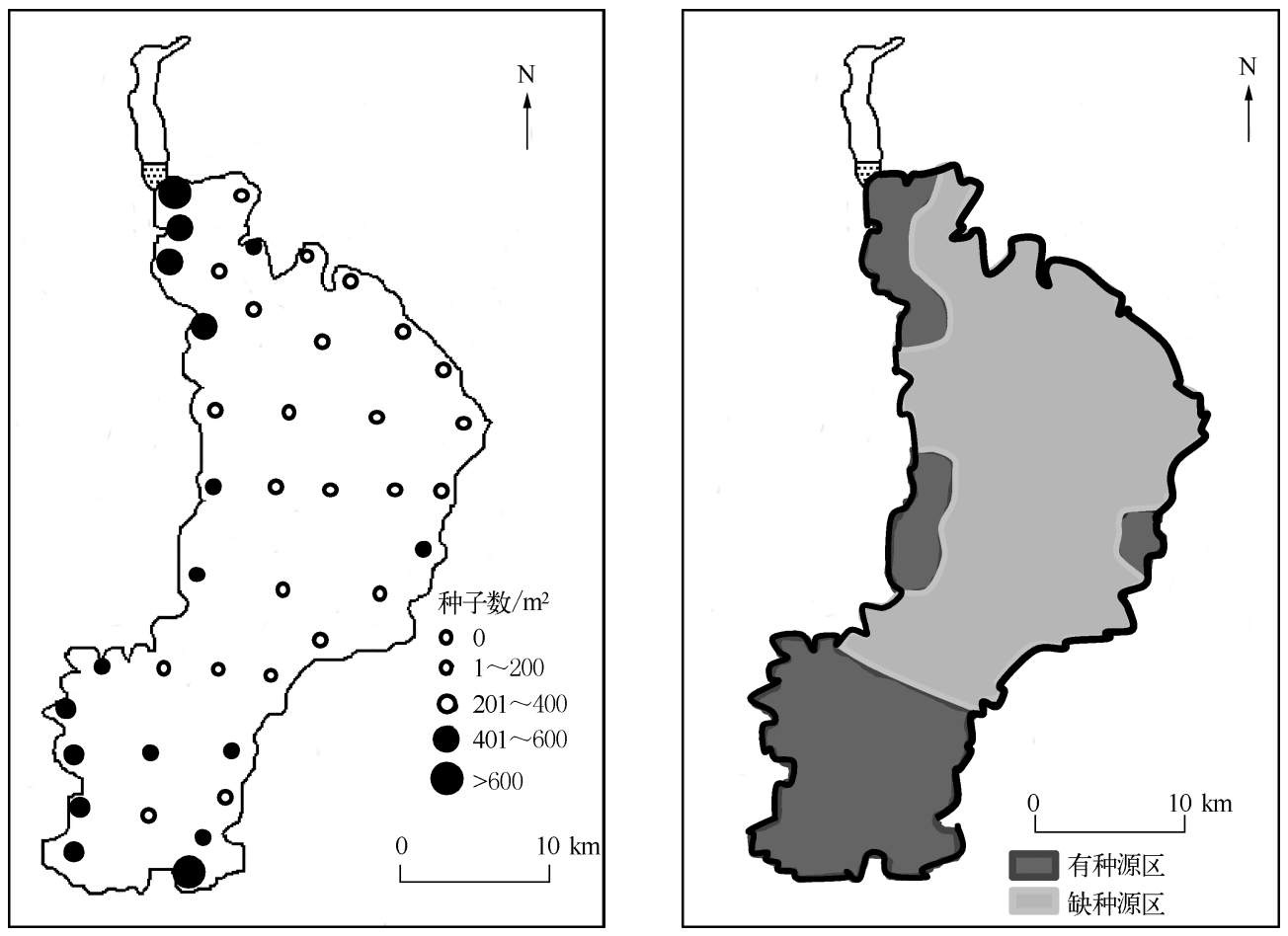

图 7 滇池表层种子库中沉水植物种子数分布及具有自我恢复潜力的区域

Fig. 7 Seed densities of sediment seed bank within sediment strata and regions with self-recovery potential in Lake Dianchi

滇池浮叶植物群落类型较少, 且分布面积很小, 除了菱群落在滇池西岸的晖湾和海口有一定面积的残 存外, 苦菜群落、水鳖群落、睡莲群落自然残存量均非常少, 在人工清退滇池湖滨的鱼塘和适宜生长的区域 零零星星有一些分布,但面积均非常小,盖度也较低.

沉水植物群落在水深 $3 \mathrm{~m}$ 以内的区域有分布, 主要在水深 $2 \mathrm{~m}$ 以内湖岸线向湖心延伸 $200 \sim 500 \mathrm{~m}$ 的水 体中呈条带状分布, 沉水植被分布约占全湖水面积的 4.5\% . 沉水植被较 $1980 \mathrm{~s}$ 末在分布面积上有所增加, 但优势种由穗状狐尾藻 (Myriophyllum spicatum) 变化为更耐污的蓖齿眼子菜, 且蓖齿眼子菜形成了绝对优 势, 物种组成更为单一. 1980s - 1990s 还有一定面积分布的蕰草、苦草群落目前在滇池开放性水体中极少有 分布, 苦草只有少数几丛分布于滇池南部和西部的湖湾中, 蕰草只在滇池湖滨的水塘有零星分布. 但让人欣 慰的是 $1970 \mathrm{~s}$ 曾经报道消失的轮藻群落, 本次调查发现在滇池海丰湖湾中尚有一定面积的分布; 微齿眼子菜 (Potamogeton maackianus) 群落、马来眼子菜 (P. malaianus) 群落也尚有分布; 曾经消失的高原湖泊特色物 种——海菜花目前也已在滇池湖滨鱼塘中引种成功, 可大面积修复性种植.

总体来说, 滇池的水生植被的群落结构和分布特征有以下几个特点: 人为干扰导致自然湖滨带所剩无 几, 所剩的具有一定自然属性的残存湖滨带主要位于河口的湖滨地带及湖湾区域, 呈现南部及西南部较多、 北部及东北部较少的分布特点; 耐污水生植物群落占优势, 如萃草群落、菎齿眼子菜群落; 环境敏感植物群 落有所保留或恢复, 如轮藻、微齿眼子菜、马来眼子菜.

\section{3 生态区划分}

生态区是根据地区的生态一致性和生物生产潜力的相似性而划分的自然区域. 生态一致性主要指 自然生态系统功能特征的相似程度. 在我国现有的水体生态分区的研究上, 大多基于水体的功能或水 
体生境来划 分 $^{[14-16]}$. 滇池生态分区针对滇池 生态系统管理的需要而提出,与传统的自然地 理分区不同,滇池生态分区过程更多考虑的是 湖泊岸带和生态系统组分的特征,力图通过岸 带结构、水质状况和生态系统组分来反映不同 尺度下的滇池生态系统格局. 因此, 以滇池不 同尺度的生态系统以及影响因素为对象,运用 生态学中的格局等原理和方法, 对滇池水体及 近岸带进行区域分类,不仅可以反映生态系统 在不同区域的生态格局特征或受损程度,而且 更为重要的是为生态系统管理及措施的制定 提供了科学依据. 本文中,生态格局划分结合 生境及生态系统组分的功能特征, 指标体系只 挑选生境特征指标、水质指标及生态学指标.

滇池生态系统空间格局特征体现在两个方 面:一是生境片段化,环湖岸带结构差异明显;二 是生态系统组成的成分分布异质性高. 在生境结 构上,滇池北岸受西南风影响,处于下风口. 南部 水质较好, 湖外有众多鱼塘分布. 滇池东岸直立 岸带林立,在环湖公路至湖面水体,鱼塘众多. 西 部处于西山下,几乎没有岸带.

基于调查结果、生态格局特征和湖岸带结 构,通过现场调查和聚类分析, 将滇池划分 5 个 生态区 (图 8): 草海重污染区 ( I )、藻类聚集区

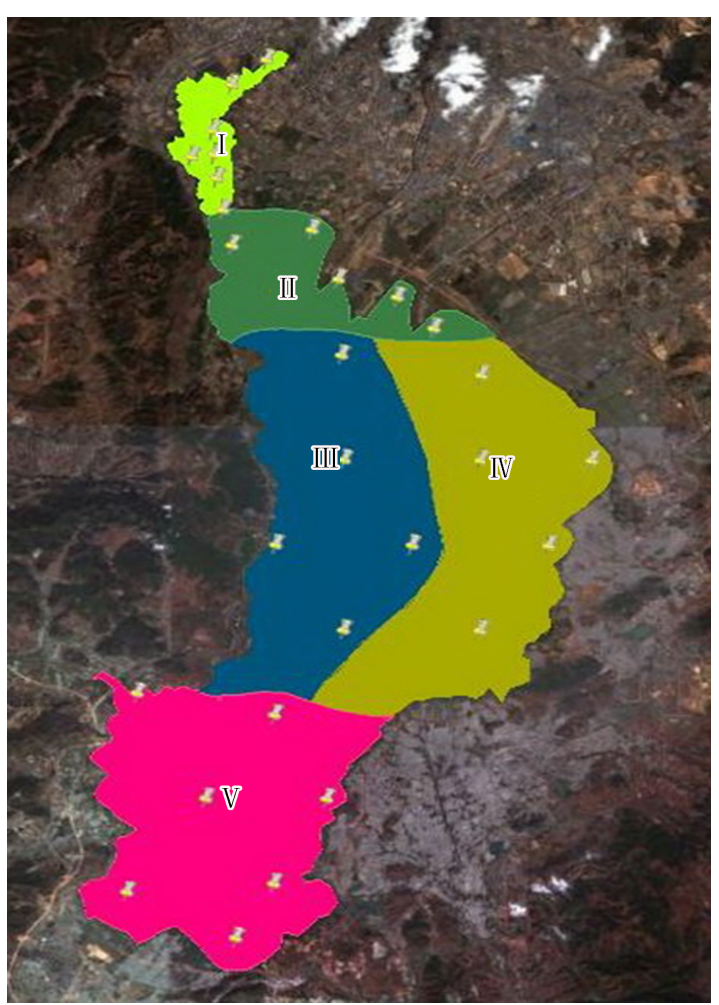

图 8 滇池的生态分区

Fig. 8 Ecoregions of Lake Dianchi

( II )、沉水植被残存区 $($ III ) 、近岸带受损区 $(I V)$ 及水生植被受损区 $(V)$. 各区的主要特征指标见表 4 .

表 4 滇池生态区的特征值

Tab. 4 Characteristics values of ecoregions in Lake Dianchi

\begin{tabular}{|c|c|c|c|c|c|c|}
\hline \multirow[b]{2}{*}{ 生态分区 } & \multicolumn{3}{|c|}{ 水质状况 } & \multicolumn{2}{|l|}{ 生物状况 } & 物理状况 \\
\hline & $\begin{array}{c}\mathrm{TN} / \\
(\mathrm{mg} / \mathrm{L})\end{array}$ & $\begin{array}{c}\mathrm{TP} / \\
(\mathrm{mg} / \mathrm{L})\end{array}$ & $\begin{array}{l}\text { Chl. a/ } \\
(\mu \mathrm{g} / \mathrm{L})\end{array}$ & 水生植被 & 种子库 & 岸带性状 \\
\hline 草海重污染区 & 7.63 & 0.60 & 122 & 多为漂浮植物 & 少 & 观光大堤 \\
\hline 藻类聚集区 & 3.84 & 0.31 & 205 & 水生植被较少 & 有 & 防浪堤 \\
\hline 沉水植被残存区 & 2.26 & 0.18 & 90 & 种类数多、盖度高 & 有 & 陡岸, 湖滨带狭小 \\
\hline 近岸带受损区 & 2.23 & 0.18 & 103 & 挺水植被恢复较好 & 无 & 防浪堤分割湖滨与众多鱼塘和农田系统 \\
\hline 水生植被受损区 & 2.40 & 0.16 & 78 & $\begin{array}{l}\text { 沉水植物分布面积 } \\
\text { 和现存量高 }\end{array}$ & 保存较好 & 防浪堤围成的较大湖湾, 堤内大片鱼塘 \\
\hline
\end{tabular}

$* \mathrm{TN} 、 \mathrm{TP} 、 \mathrm{Chl} . \mathrm{a}$ 为多年平均值.

\section{3 滇池水生态的分区分步治理新策略}

\section{1 滇池生态系统治理的问题}

滇池水污染治理在过去的十几年里,地方和国家投人大量人力物力, 虽然取得了一些成绩, 但治理效果 并不理想. 这不仅有湖泊生态复治理基础理论研究不足的问题, 也有滇池治理理念问题. 关于基础理论研究 不足的问题有关文献做了详细的阐述 ${ }^{[17]}$, 因此这里只谈治理理念的问题. 
1) 科学性和系统性认识不够导致重控污、轻生态修复.

滇池在 1996 年第四次全国环保工作会议上被列为全国重点治理的“三河三湖”之一, 滇池水污染防治 被列人全国环保“九五”重点工程. 滇池的水污染治理开始了工程治理之门, 经历“九五”、“十五”、“十一 五” 的综合整治, 滇池富养化进程得到遏制, 但由于滇池治理工作基础性研究薄弱, 对湖泊自然规律和流域 经济社会发展规律认识不深, 编制的治理规划缺乏科学性和系统性, 操作性不强, 致使滇池治理没有达到如 期的效果. 由于对滇池治理思路科学性和系统性认识不够, 导致重控污、轻生态修复, 从地方政府治理投人 资金分布上窥见一斑: 3 个五年计划中地方政府共计投人 222.3 亿元, 其中 $58 \%$ 用于污染治理, $21 \%$ 用于生 态修复 ${ }^{[18]}$.

重控污、轻生态修复的思想主要体现在两个方面: 其一是认为, 只要控制了污染, 生态系统自然会自我 修复, 这种认识过于夸大了受损生态系统的自我修复功能. 其二是, 污染必须要控制到一定程度 (越过生态 系统崩溃点), 生态系统才能进行恢复, 这种认识过于形而上学了.

在较高的污染条件下, 恢复水生植被并不是不可行. 在滇池外草海现有的理化参数 ( TP: $0.60 \sim$ $0.92 \mathrm{mg} / \mathrm{L}, \mathrm{TN}: 5.0 \sim 11.4 \mathrm{mg} / \mathrm{L}, \mathrm{NH}_{4}^{+}-\mathrm{N}: 0.60 \sim 0.83 \mathrm{mg} / \mathrm{L}$ ) 远远超过经典的长江下游浅水湖泊稳态转换的 营养阈值范围. 通过生态修复条件创建、水生植被构建和水生植被维护技术的优化与集成, 建成了以轮叶黑 藻 (Hydrilla varticillata) 为优势种群的水生植被生长区, 进而促进浊水态向草型清水态的转换 (运行期达 2 年). 沉水植被盖度达 $80 \%$ 以上, 在沉水植被生长期, 水清澈见底, 水质改善效果明显, 示范区的 TN 下降 $60 \%$ 、TP 下降 $54 \%$. 技术研发与示范结果表明, 在严重受损的水生态系统中, 通过人工措施, 恢复并维持了 草型清水态.

2) 滇池生态环境退化原因和异质性认识不够导致全湖治理无区分对待.

滇池是云贵高原面积最大的淡水湖泊, 水域面积 $310 \mathrm{~km}^{2}$. 北岸承接昆明主城区, 受纳主城区的污水, 西 岸有西山环抱, 南岸为滇池出水口, 东岸地势开阔, 多为农田. 常年盛行西南风.

多年的水体富营养化导致生态系统退化, 水文特征导致的滇池营养物分布、水生生物分区分布的生态 系统格局特征明显. 不同湖区所处的生态系统退化阶段也不一样. 对这样一个水域面积大、生态格局特征异 质的湖泊采取单一的技术治理是行不通的, 不区别对待地进行技术 “移植”也是不行的. 水深和透明度是影 响沉水植物分布的关键因素, 而风浪是影响透明度和植物定植的直接原因之一. 因此, 在滇池北岸和东岸, 滇池外海东岸和北岸的沉水植物种群数量分布较少且种群结构单一. 在这种情况下, 在北岸污染严重的水 华堆积区进行生态修复是得不偿失的.

对滇池生态环境的异质性和退化原因认识不够是前一阶段的脈病, 也是治理过程的问题所在.

\section{2 滇池治理新理念}

在了解滇池生态系统退化的原因、滇池生态系统当前的格局特征后, 总结前期的治理经验, 基于生态格 局特征和湖岸带结构, 通过现场调查和聚类分析, 将滇池划分 5 个生态区, 即, 草海重污染区、藻类聚集区、 沉水植被残存区、近岸带受损区、水生植被受损区. 那么,基于对滇池生态系统结构、分区环境生态特征的解 析, 认为滇池生态系统修复思路应该转变. 今后, 滇池的治理应遵循分区分步治理的思路和“南部优先恢复; 北部控藻治污; 西部自然保护; 东部外围突破” 的总体方案, 稳步实现从水质改善到生态系统管理的过渡.

\section{3 滇池分区分步治理的方案设计}

按照 “一区一策” 的思路, 对滇池水体生态系统的结构和功能进行改造、构建, 对现有的水生植物群落进 行保护, 营造适宜的环境条件, 促使其种群自然扩增, 达成控制滇池巨大蓝藻水华生物量的目的, 进而促进 生物多样性的增加, 为滇池水体生态系统向好的方面转化, 最终为滇池富营养化问题的全面解决做出应有 的贡献(图 9).

1) 草海水生植被恢复工程: 外草海 $7 \mathrm{~km}^{2}$ 的区域为工程实施区, 在此区的西边为工程的核心区 $\left(1.5 \mathrm{~km}^{2}\right)$, 为工程的的实施提供种源、实验基地; 外草海南部的新疏浚区 $\left(1.3 \mathrm{~km}^{2}\right)$ 为缓冲区, 开展底泥疏 浚条件下植被构建工程; 外草海东边硬质护岸区为景观改善区, 开展硬质护岸、码头景观构建工程. 恢复后 的水生植物盖度不小于 $40 \%$, 水生植被恢复区水质( TP、TN) 浓度较基准年下降 $30 \%$ 以上; 生物多样性提高, 自然生态景观得到根本改善. 
2) 滇池北部蓝藻水华控制工程:在滇池水体营 养水平未得到有效控制之前, 突出重视滇池北岸水 体控藻效果, 遵循安全适用的经济的指导思想和原 则,工程方案采取机械大规模清除技术,处置滇池 北部堆积的水华蓝藻.在短时间内全面大幅度削减 滇池水体蓝藻水华的发生量. 控制滇池北部区域约 $30 \mathrm{~km}^{2}$. 在北部的东岸和西岸建设收藻场. 工程建成 运行 2 年后,滇池蓝藻水华发生量较工程建成前削 减 30\% ; 建成运行 4 年后,削减量达到 50\% ; 逐步消 除北部蓝藻水华堆积,改善周边生态环境.

3) 滇池东岸塘一湖生态系统构建工程:滇池东 岸福保至呈贡县与晋宁县交界的湖滨带核心区面 积约 $20 \mathrm{~km}^{2}$. 从以下 4 个方面进行设计规划: 防浪堤 处置、塘库系统构建、基底修复和生态建设. 最终目 标是为了沟通湖滨消落带水陆交错生态系统结构 的天然联系, 恢复湖滨带原有的自然环境属性.

4) 滇池南岸生态恢复工程:适用区域为滇池南 岸湖滨带,西始西山区海口镇海门村, 东至晋宁县 新街乡三合村的湖滨地区, 面积约 $36 \mathrm{~km}^{2}$. 项目建 设内容为适用区东侧三合至梁王及海口湖滨带开 展的湿地恢复与保护工程, 以及南侧石寨至古城湖 滨开展的湖一塘连通区生态修复工程.

5) 滇池西岸水生植被保护工程: 滇池西岸沿线 湖滨现有植被, 以水生植被保护为主, 兼顾旱生和 湿生植被保护. 沿滇池西岸高海路以东湖滨带自北

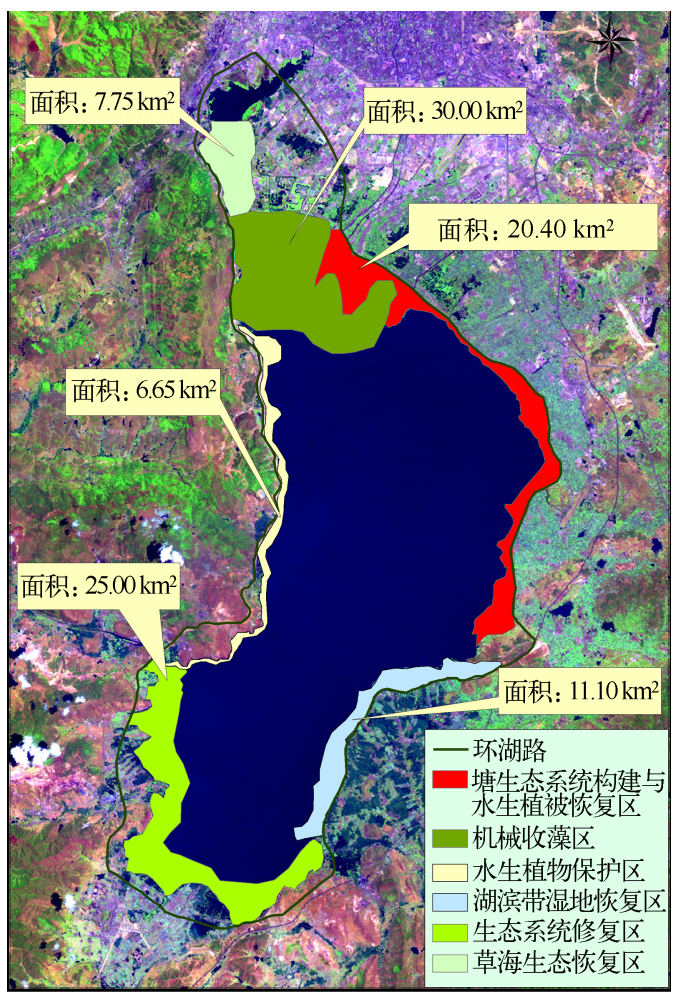

图 9 滇池分区分步的治理方案

Fig. 9 Program of ecoregion and step-by-step implementation in Lake Dianchi 向南, 北自晖湾村始, 向南顺高海公路, 经富善、西 华、观音山、百草、白鱼口,至海口大桥湖滨沿线的滇池水体和湖滨带部分地区,划人保护区. 水体距防浪堤 水平距离不低于 $200 \mathrm{~m}$,面积约 $6.65 \mathrm{~km}^{2}$.

\section{4 讨论与结论}

1990s 以来, 滇池水环境迅速恶化,生态系统发生严重退化,一些服务功能基本丧失 ${ }^{[17-19]}$. 国家和地方政 府下大力气, 投人大量财政支持滇池水环境的治理,尽管恶化趋势得到有效遏制, 但效果远未达到社会的心 理预期 ${ }^{[20-21]}$. 本研究指出, 只有辨析滇池生态系统退化原因和当前滇池生态格局特征, 才能在治理实践中避 免盲目, 找到针对性的治理措施和技术, 促进滇池蓝藻水华的控制和滇池生态系统的好转. 鉴于此, 可以考 虑转换滇池治理思路,针对滇池生态系统空间格局的异质性,各区的水环境特性及其所处的退化阶段,采用 不同的治理措施,即分区分步恢复滇池生态系统的策略,以期达到事半功倍的效果.

1) 滇池生态系统退化主要原因: 污染物持续输人以及围湖造田、直立堤岸和水量交换缓慢等外力干扰 加剧系统组分失衡是直接的外部原因; 滇池所处的地理位置、气候等原因, 使得滇池水华蓝藻对营养盐增加 的响应远高于其他湖泊 (太湖、巢湖) ; 高原湖泊滇池生态系统相对脆弱, 如物种的同域分化、窄生态位, 导致 系统的稳定性差、自我修复能力弱.

2) 当前,滇池生态系统格局特征异质性高. 整个滇池生态系统可划分为草海重污染区、藻类聚集区、沉 水植被残存区、近岸带受损区、水生植被受损区 5 个生态区. 针对各区的生态特征, 可采用不同的工程措施, 按照分区分步的治理策略,实现滇池水体生态系统向好的方面转化.

致谢: 本文部分数据来源于“十一五水专项”滇池项目第五课题组成员的研究结果,在此深表感谢! 


\section{5 参考文献}

[ 1 ] 于希贤. 滇池历史地理初步研究. 云南地理环境研究,2003,15(4) :32-38.

[2]吴玉书,陈因硕, 肖家仪. 滇池地区四万年以来的植被和气候演变初步研究. 植物学报, 1991,33(6):450-458.

[ 3 ] 段琪彩,黄 英,柏绍光. 滇池蓄清排污调度方案探析. 水资源保护,2012,28(5): 75-79.

[4]罗民波,段昌群,沈新强等. 滇池水环境退化与区域内物种多样性的丧失. 海洋渔业,2006,28(1):71-78.

[ 5] 杨健强. 滇池污染的治理和生态保护. 水利学报,2001,(5) :20-22.

[6] 余 冬,赵世民,李发荣. 昆明城市污水处理现状及对治理滇池的影响分析. 环境科学导刊,2008,27(6):47-48.

[ 7 ] 孙金华,曹晓峰,黄 艺. 滇池水质时空特征及与流域人类活动的关系. 湖泊科学,2012,24(3):347-354.

[8] 昆明市环境科学研究所. 滇池富营养化调查研究. 昆明:云南科技出版社, $1992: 118$.

[9] 张 梅, 李 原, 王若南. 滇池浮游植物的生物多样性调查研究. 云南大学学报: 自然科学版, 2005, 27 (2): 170-175.

[10］王丑明,谢志才, 宋立荣等. 滇池大型无脊椎动物的群落演变成因分析. 动物学研究,2011,32(2):1-10.

[11] 王丽珍,徐小清, 周文博等. 云南滇池马村湾、海东湾底栖动物本底调查研究. 云南大学学报: 自然科学版,2002,24 (2) : 134-139.

[12] 王丽珍,刘永定,陈 亮等. 滇池底栖无脊椎动物群落结构及水质评价. 水生生物学报, 2007,31(4):590-593.

[13] 曲仲湘,李 恒. 滇池植物群落和污染. 见: 曲仲湘编. 滇池污染和水生生物. 昆明: 云南人民出版社, 1983:7-15.

[14] 李 博, 雍世鹏, 曾泗弟等. 生态分区的原则、方法与应用一内蒙古自治区生态分区图说明. 植物生态学与地植 物学学报, $1990,14(1): 55-62$.

[15] 杨一光. 试论生态分区的概念、等级单位和划分依据一以云南省为例. 云南大学学报: 自然科学版, 1994,16(3): 189-194.

[16] 孟 伟,张 远,郑丙辉. 辽河流域水生态分区研究. 环境科学学报,2007,27(6):911-918.

[17] 秦伯强,高 光,胡维平等. 浅水湖泊生态系统恢复的理论与实践思考. 湖泊科学,2005,17(1):9-16.

[18］郁亚娟,王 翔,王 冬等. 滇池流域水污染防治规划回顾性评估. 环境科学与管理,2012,37(4):184-189.

[19] 蔡佳亮, 苏 玉, 文 航等. 滇池流域人湖河流丰水期大型底栖动物群落特征及其与水环境因子的关系. 环境科 学,2011,32(4):982-989.

[20］郭怀成,王心宇,伊 璇. 基于滇池水生态系统演替的富营养化控制策略. 地理研究,2013,32(6):998-1006.

[21］李中杰,郑一新,张大为等. 滇池流域近 20 年社会经济发展对水环境的影响. 湖泊科学,2012,24(6):875-882. 